\title{
THE EFFECT OF A COPPER-RELEASING INTRAUTERINE DEVICE ON SPERM PENETRATION IN HUMAN CERVICAL MUCUS IN VITRO
}

\author{
MAX ELSTEIN AND KAREN FERRER \\ Human Reproduction and Obstetrics, Faculty of Medicine, University of Southampton
}

(Received 7th fuly 1972)

Improvements in the acceptability and effectiveness of the IUD involve developments in design of its shape such as the Dalkon Shield (Davis, 1971), or the addition of a copper-releasing wire to the inert plastic material of the device, which was first reported by Zipper, Medel \& Prager (1968). The copper could act at any stage in the reproductive process. It could interfere with sperm transport, destroy the fertilized egg or blastocyst, disturb the intrauterine environment preventing implantation, or might owe its effectiveness to a combination of actions.

In rats, the presence of copper in one uterine horn does not affect implantation in the other horn (Chang \& Tatum, 1970), indicating that the effect is local. It was also observed in rats that a copper implant in the uterus did not interfere with fertilization but prevented implantation. It has been suggested that this prevention of implantation may be due to the specific attraction of leucocytes into the uterine lumen (Cuadros \& Hirsch, 1972). It is not possible, however, to extrapolate completely from animal experiments to man as reproductive mechanisms vary considerably.

We decided to study the effect of the copper released from these IUDs on the transport of spermatozoa through cervical mucus, the physical properties of which vary throughout the menstrual cycle. Sperm penetration is maximal at mid-cycle when the mucus is of low viscosity and free of cells and exhibits the rheological property of spinnbarkeit.

Cervical mucus was obtained from normal women at mid-cycle and incubated with a copper-coated stem of the Gravigard IUD (Searle) in a humidity chamber at $37^{\circ} \mathrm{G}$ for $20 \mathrm{hr}$. Another portion of each mucus sample was incubated for the same length of time without a copper IUD. The average volume of each sample incubated was $0.2 \mathrm{ml}$. After $20 \mathrm{hr}$, the spinnbarkeit of each sample was tested (Clift, 1945), and a capillary sperm penetration test was performed (Kremer, 1965), using normal motile spermatozoa from the same specimen of semen which was used for each pair of mucus samples. The linear penetration of the spermatozoa was recorded in millimetres, and their motility was assessed. A portion of the mucus was also assayed for copper, using spectrophotometry and oxalydihydrazide based on a method described by Rice (1960).

After incubation with the copper, there was a loss of spinnbarkeit. The mucus became watery and could not be drawn out into threads, confirming the findings 
of Oster (1972), who had suggested that this effect might be due to an interference with the disulphide bondings of the glycoproteins which form the main structural component of the mucus.

Analysis of the data by the paired $t$ test showed that there was a significant $(P<0.001)$ decrease in sperm penetration in the mucus samples incubated with the copper IUD (Table 1), and in most of the treated mucus samples the spermatozoa were immotile after incubation for $30 \mathrm{~min}$. The concentration of copper in the specimens of mucus in vitro were of a similar order to those found in the cervical mucus of patients with a copper IUD in situ.

Table 1. Sperm penetration of human cervical mucus in vitro

\begin{tabular}{c|c|c}
\hline \multirow{2}{*}{$\begin{array}{c}\text { Mid-cycle cervical } \\
\text { mucus sample }\end{array}$} & \multicolumn{2}{|c}{ Distance of sperm penetration $(\mathrm{mm})$} \\
\cline { 2 - 3 } & Control & Copper IUD \\
\hline 1 & 18 & 15 \\
2 & 20 & 5 \\
3 & 10 & 12 \\
4 & 10 & 5 \\
5 & 14 & 5 \\
6 & 17 & 11 \\
7 & 40 & 20 \\
8 & 24 & 12 \\
9 & 35 & 12 \\
10 & 21 & 14 \\
11 & 23 & 16 \\
12 & 28 & 13 \\
13 & 25 & 7 \\
14 & 24 & 13 \\
15 & 45 & 26 \\
16 & 20 & 9 \\
17 & 29 & 17 \\
18 & 47 & 17 \\
19 & 41 & 29 \\
20 & 40 & 0 \\
21 & 45 & 10 \\
22 & 20 & 5 \\
\hline
\end{tabular}

The changes in the rheological properties of the cervical mucus causing the apparent disappearance of the longitudinally arranged structural units (Elstein, Mitchell \& Syrett, 1971) do not prevent sperm penetration. Kremer (1965) observed that spermatozoa pentrated almost as far into serum as into mid-cycle mucus. Therefore, the reduction in penetration is likely to be caused by a direct toxic effect of the copper on the spermatozoa (Zipper et al., 1968).

We suggest that at least one of the ways in which a copper-releasing IUD exerts its contraceptive action is by a direct toxic effect upon spermatozoa. Further studies are in progress to assess the mechanism of the copper IUD as an anti-implantation agent by changes invoked in endometrial function or by a possible lethal effect on fetal cells.

K.F. was the recipient of a Research Fellowship granted by G. D. Searle. Statistical analyses of the data were carried out by Dr Martin Gardner of the Department of Community Medicine in the Medical Faculty of Southampton University. 


\section{REFERENCES}

Ghang, C. C. \& Tatum, H. S. (1970) The effect of intrauterine copper and other metals on implantation in rats and hamsters. Fert. Steril. 21, 274.

GuIft, A. F. (1945) Observations of certain rheological properties of human cervical secretions. Proc. R. Soc. Med. 39, 1.

Guadros, A. \& Hirsch, J. G. (1972) Copper on intrauterine devices stimulates leukocytes exudation. Science, $\mathcal{N} . X .175,175$.

DAvis, H. J. (1971) Intrauterine devices for contraception. Williams \& Wilkins, Baltimore.

Elstein, M., Mttchell, R. F. \& Syretr, J. T. (1971) Ultrastructure of cervical mucus. 7. Obstet. Gynaec. Br. Commonw. 78, 180.

Kremer, J. (1965) A simple sperm penetration test. Int. F. Fert. 10, 209.

Oster, G. K. (1972) Ghemical reactions of the copper intrauterine device. Fert. Steril. 23, 19.

Rrce, E. W. (1960) Spectrophotometric determination of serum copper with oxalydihydrazide. F. Lab. clin. Med. 155, 325.

Zipper, J., Medel, M. \& Prager, R. (1968) Alteration in fertility induced by unilateral intrauterine installation of cytotoxic compound in rats. Am. J. Obstet. Gynec. 101, 971. 